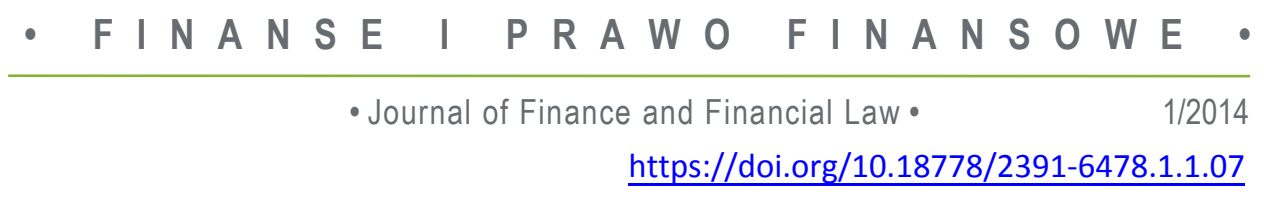

Magdalena Szczepańska

Doktorantka, Uniwersytet Łódzki,

Wydział Prawa i Administracji,

Katedra Prawa Finansowego

\title{
CHARAKTER PRAWNY KONTROLI PODATKOWEJ W UJECCIU FUNKCJONALNYM
}

\begin{abstract}
Trzeba zawsze pamiętać, że kontrola jest środkiem, a nie celem.
Jeżeli więc można mówić o zbyteczności lub zmniejszeniu kontroli, to tylko rozumiejac pod tym jej niepotrzebny nadmiar,

nigdy zaś sama zasadę kontroli.

[za: Kurowski i Sochacka-Krysiak 1990:50-51]
\end{abstract}

\section{Streszczenie}

Artykuł poddaje analizie charakter prawny instytucji kontroli podatkowej z uwzględnieniem koncepcji funkcji prawa. Tekst podejmuje problematykę miejsca kontroli podatkowej w ramach innych procedur podatkowych przewidzianych w Ordynacji podatkowej. Tekst odnosi się też do funkcjonalnej koncepcji budowy Ordynacji podatkowej rozważając miejsce kontroli podatkowej w zaproponowanym układzie. Autorka uzasadnia potrzebę odrębności kontroli podatkowej jako autonomicznej procedury oraz proponuje niektóre kierunki zmian w ramach tej instytucji.

Słowa kluczowe: kontrola podatkowa, funkcje, rezultat kontroli, cel kontroli.

\section{WPROWADZENIE}

Procedura kontroli podatkowej uregulowana jest w dziale VI (art. 281-292) Ustawy z dnia 29 sierpnia 1997 r. Ordynacja podatkowa (dalej o.p.). U podstaw badania charakteru prawego kontroli podatkowej leży ustalenie funkcji jakie pełnią jej poszczególne regulacje na tle innych instytucji i procedur, których przedmiotem są sprawy podatkowe.

W teorii prawa o funkcjach mówi się kontekście zarówno pojedynczych norm, ale i grup norm prawnych, czy też instytucji prawnych. Teoria funkcjo- 
nalna wymienia 3 typy funkcji, które w rozważaniach o prawie znajdują najszersze zastosowanie, a mianowicie [Bogucka 2000: 67-93]:

- funkcja roli (sposobu działania),

- funkcja celu,

- funkcja skutku (rezultatu).

W literaturze podkreśla się jednak, że funkcja roli sprowadza się do określonego sposobu działania, pewnej całości stosownie do swojej natury i przeznaczenia. W nauce prawa pojęcie funkcji sposobu działania (funkcji roli) pojawia się rzadko, gdyż funkcja w rozważaniach o prawie najczęściej daje się analizować z punktu wiedzenia kategorii celu (funkcji założonych) lub kategorii następstw działania, tj.: skutków [Bogucka 2000: 47].

\section{KONTROLA PODATKOWA W UJĘCIU FUNKCJONALNYM}

Podejmując rozważania nad funkcją kontroli podatkowej należy w pierwszej kolejności umiejscowić ją względem równoważnej płaszczyzny badawczej.

Względem nauk prawnych w ogóle (według kryterium zewnętrznego) kontrola podatkowa to model kontroli finansowej. O charakterze tej instytucji przesądzają w szczególności:

- przedmiot kontroli podatkowej determinowany przez charakter stosunku prawnego zobowiązania podatkowego,

- określony schemat działania, na który składają się:

1. ustalenie stanu obowiązującego, tzw. wyznaczeń, tj.: stwierdzenie co w danym wypadku konkretnie obowiązuje,

2. ustalenie stanu faktycznego (rzeczywistego), tzw. wykonań,

3. porównanie wykonań z wyznaczeniami w celu ustalenia ich zgodności lub niezgodności - istota każdego procesu kontroli,

4. wyjaśnienie przyczyn stwierdzonej zgodności lub niezgodności między wykonaniami a wyznaczeniami [Kurowski i Sochacka-Krysiak 1990: 24-25].

Względem innych postępowań w sprawach zobowiązań podatkowych (w oparciu o kryterium wewnętrzne) o charakterze kontroli podatkowej przesądzają głównie 2 czynniki:

- cel

- rezultat $^{1}$.

${ }^{1} \mathrm{~W}$ tym kontekście można też mówić o analizie przez pryzmat funkcji jako skutku: Bogucka [2000: 67-93]. 


\subsection{Cel kontroli}

Normatywne określenie celu kontroli jest zadaniem trudnym, nie sposób precyzyjnie wyartykułować celu instytucji o tak niejednoznacznym wykorzystaniu.

Procedura kontroli podatkowej w aktualnym stanie prawnym identyfikowana jest jako zespół czynności podejmowanych przez organy podatkowe pierwszej instancji mające na celu sprawdzenie czy określone w przepisach podmioty prawa podatkowego wywiązują się z obowiązków wynikających z przepisów prawa podatkowego [Ustawa z dnia 29 sierpnia 1997 r., art. 281, §2]. W literaturze funkcjonuje również pogląd, że przedmiotem kontroli podatkowej może być również sprawdzenie czy kontrolowany prawidłowo korzysta $\mathrm{z}$ uprawnień podatkowych przyznawanych w oparciu o określone w przepisach prawa przesłanki [Popławki 2009: 1069].

Cel kontroli w Ordynacji podatkowej został określony wąsko i oddzielony przez ustawodawcę od władczych rozstrzygnięć w sprawach podatkowych. Tak określony cel odpowiada klasycznemu założeniu modelowemu kontroli kończącej się stwierdzeniem i wyjaśnieniem stosunku między rzeczywistością a wyznaczeniami, w odróżnieniu od mniej popularnej rozszerzonej koncepcji, według której kontrola obejmuje również działalność pokontrolną doprowadzającą do zgodności wykonań i wyznaczeń poprzez wydanie decyzji (w sensie prakseologicznym) [Kurowski i Sochacka-Krysiak 1990: 28-29].

Fiskalne kryterium określenia celu czynności kontrolnych w sprawach zobowiązań podatkowych odnajdujemy również w uzasadnieniu do projektu ustawy Ordynacja podatkowa, w którym to ustawodawca sygnalizuje konieczność wyposażenia organów podatkowych w takie instrumenty kontroli, które pozwolą im na łatwe i szybkie dochodzenie należności przysługujących Skarbowi Państwa lub gminie.

\subsection{Rezultat kontroli - następstwa kontroli}

Bezpośrednim, materialnym rezultatem przeprowadzonej kontroli podatkowej jest zgromadzony w jej trakcie materiał dowodowy. Dowody zebrane podczas kontroli podatkowej stanowią podstawę ustalenia stanu faktycznego sprawy. Dopiero bowiem ustalenie podatkowego stanu faktycznego sprawy umożliwia sformułowanie treści rezultatu kontroli tj.: potwierdzenia przez organ prawidłowego bądź nieprawidłowego sposobu postępowania podmiotu w zakresie realizacji obowiązków nałożonych na niego przepisami prawa podatkowego. Potwierdzenie takie przybiera urzędową formę protokołu kontroli. 
Nie jest to jednak jedyne następstwo przeprowadzonych $w$ trakcie kontroli czynności. Treść rezultatu kontroli rodzi bowiem kolejne następstwa jakimi mogą być:

- korekta (art. 81, §1-81b, §1 o.p., też art. 14c-14c ust. 2 u.k.s. ${ }^{2}$ ), w tym związana z przedmiotem kontroli np.: zobowiązanie w konkretnym podatku za dany okres rozliczeniowy ${ }^{3}$. Kontrola podatkowa może mieć też skutek szerszy, dzieje się tak w sytuacji kiedy np. jedna korekta będąca konsekwencją kontroli w podatku od towarów i usług wpłynie na konieczność skorygowania zobowiązania w podatku dochodowym (w takiej sytuacji można też mówić o prewencyjnej roli kontroli podatkowej);

- wszczęcie postępowania podatkowego prowadzącego najczęściej do wydania decyzji selektywnej w sytuacji kiedy w toku kontroli stwierdzono nieprawidłowości oraz nie doszło do ich usunięcia w drodze korekty lub złożenia zeznania w ogóle. Podstawy dla wszczęcia takiego postępowania odnajdujemy w art. $165 \mathrm{~b} \$ 1$ o.p. ${ }^{4}$ oraz art. 21 \$3-3a o.p. W literaturze wskazuje się, że $\mathrm{z}$ art. $165 \mathrm{~b} \S 1$ o.p. wynika wręcz obowiązek wszczęcia postępowania podatkowego przez organy podatkowe w sprawie, która była przedmiotem kontroli [Kaczyński i Charkiewicz 2012: 232];

- utrwalenie samowymiaru - w sytuacji kiedy w następstwie przeprowadzenia kontroli organ podatkowy nie stwierdzi nieprawidłowości lub uwzględni w całości zastrzeżenia ${ }^{5}$ podmiotu, można wówczas mówić o pewnego rodzaju „utrwaleniu" samowymiaru, jako aktu przestrzegania i stosowania prawa przez ten podmiot ${ }^{6}$.

Powyżej opisane rezultaty przeprowadzenia kontroli podatkowej przesądzają o niejednoznacznym charakterze tej instytucji. Fakt, iż organ podatkowy w następstwie kontroli może wszcząć postępowanie doprowadzając do skorygowania zobowiązania powoduje, że trudne wydaje się wyznaczenie granicy pomiędzy działaniami kontrolnymi a postępowaniem podatkowym. Tym bar-

${ }^{2}$ Art. 14c. 1. Uprawnienie do skorygowania deklaracji, określone w art. 81 Ustawy z dnia 29 sierpnia 1997 r. - Ordynacja podatkowa, ulega zawieszeniu na czas trwania postępowania kontrolnego w zakresie objętym tym postępowaniem, z zastrzeżeniem ust. 2.

2. Kontrolowany może, w terminie wyznaczonym zgodnie z art. 24 ust. 4 (przed wydaniem decyzji lub wyniku kontroli organ kontroli skarbowej wyznacza kontrolowanemu 7-dniowy termin do wypowiedzenia się w sprawie zebranego materiału dowodowego), skorygować w zakresie objętym postępowaniem kontrolnym uprzednio złożoną deklarację podatkową.

${ }^{3} \mathrm{O}$ korekcie w toku kontroli skarbowej jako swoistym porozumieniu między podmiotem kontrolowanym a organem skarbowym w postępowaniu podatkowym pisze Pietrasz [2007: 89-93], oraz w uwagach do tego referatu Malezini [2007: 93-100]. Por. też: o możliwych kierunkach korygowania po kontroli podatkowej: Kosińska i Wolatnowski [2007: 58-60].

${ }^{4}$ Art. 165 b dodany przez art. 1, pkt 32 Ustawy z dnia 7 listopada $2008 \mathrm{r}$.

${ }^{5} \mathrm{~W}$ trybie art. 291 o.p. Szerzej na temat charakteru prawnego tej instytucji i terminu do jej wniesienia: Malezini i Zalewski [2010: 40-45]; Kubacki i Bartosiewicz [2007: 48-51].

${ }^{6}$ Szeroko na temat istoty samowymiaru: Dzwonkowski [2004: 40-51]; Dzwonkowski [2003]; Dębowska-Romanowska [1998: 23-24]. 
dziej utrudnia to fakt, iż występuje tożsamość podmiotu czynnego zarówno w jednym, jak i drugim postępowaniu.

Z drugiej strony kontrola może zakończyć się całkowitym brakiem ustaleń wymagających skorygowania, wówczas brak następstw kontroli i rezultat kontroli zawiera się w jej celu.

\subsection{Miejsce kontroli podatkowej w ramach procedur podatkowych}

Wnioski płynące z tak przeprowadzonej analizy funkcji celu i rezultatu kontroli podatkowej pozwalają na potwierdzenie, iż wyodrębnienie jej jako procedury było prawidłowe ${ }^{7}$. Co więcej, za rozwiązaniem takim przemawia również argument ekonomiki procesowej. Przejaw tego stanowić może niedopuszczenie do wszczynania postępowań w sytuacji gdy podmioty w prawidłowy sposób realizują swoje prawa i obowiązki wyznaczone przepisami prawa podatkowego. Ponadto, ustalenia stanu faktycznego i zebrane w toku kontroli podatkowej dowody stanowią materiał służący postępowaniu jurysdykcyjnemu.

Autonomiczny charakter kontroli podatkowej daje możliwość jej prowadzenia w sposób:

1) samoistny jako niezależny rodzaj postępowania w sprawach zobowiązań podatkowych,

2) na potrzeby postępowania podatkowego i kontrolnego.

Pierwszy ze sposobów nie wymaga komentarza, drugi natomiast wiązać się może w praktyce: u.k.s. ${ }^{8}$,

- z kontrolą dokonywaną przez organy kontroli skarbowej (art. 13 ust. 3

- z wystąpieniem konieczności sprawdzenia prawidłowości i rzetelności dokumentów u kontrahenta kontrolowanego podatnika (art. $274 \mathrm{c}$ o.p. ${ }^{9}$ ),

- z rozwiązaniem wynikającym pośrednio z art. 282a $\$ 2$ pkt 2 o.p. ${ }^{10}$ dotyczącym wszczęcia kontroli, jeżeli jest to niezbędne do przeprowadzenia postę-

${ }^{7} \mathrm{~W}$ opozycji do koncepcji rozszerzenia postępowania podatkowego o pozostałe procedury z Ordynacji podatkowej, w tym o kontrolę podatkową, patrz: Niezgódka-Medek [2007: 814-815]; kontrola jako element postępowania podatkowego: Mastalski i Zubrzycki [2000: 14-15]. Z kolei o kontroli jako definitywnie odrębnej procedurze: Masternak [1998: 101]; Zdanowicz [1998: 315-318].

${ }^{8} \mathrm{~W}$ art. 13 ust. 3 u.k.s. dano organowi kontroli skarbowej możliwość przeprowadzenia kontroli podatkowej w trakcie postępowania kontrolnego, jeśli uzna, że zachodzi taka potrzeba.

${ }^{9}$ Treść przepisu wskazuje na możliwość przeprowadzenia tej czynności w ramach kontroli podatkowej. Należy jednak poddać rozwadze możliwość sprawdzenia kontrahenta podatnika w ramach samoistnego postępowania podatkowego.

${ }^{10} \mathrm{Na}$ możliwość prowadzenia kontroli podatkowej ale niezależnie od toczącego się postępowania wskazywała Niezgódka-Medek [2007: 815], posiłkując się regulacją art. 282a o.p., należy jednak zauważyć, że kontrola prowadzona równolegle do postępowania stawia te procedury 
powania podatkowego w związku z sądowym wyeliminowaniem z obrotu prawnego decyzji wadliwej ${ }^{11}$. W literaturze spotkać można stanowisko, iż kontrolę podatkową prowadzić można obok równolegle toczącego się postępowania [Niezgódka-Medek 2007: 815]. Ten przypadek wymaga jednak rozważenia i komentarza, czy dopuszczalne i uzasadnione jest prowadzenie kontroli podatkowej celem ustalenia stanu faktycznego obok równolegle toczącego się postępowania podatkowego w tej sprawie. Warto w tym miejscu podkreślić, że kontrola podatkowa może, ale nie musi poprzedzać postępowania podatkowego, organ podatkowy prowadząc postępowanie podatkowe (np. wszczęte w oparciu o informacje przekazane przez organy ścigania, czy pochodzące z innych postępowań) prowadzi postępowanie dowodowe: w jego trakcie wzywa do okazania ksiąg, faktur, deklaracji, dowodów zapłaty i wówczas kontrola u podatnika stanowiłaby zbędne powielenie postępowań [Wyrok NSA z 15 lipca 2011 r.]. Wszczęcie kontroli podatkowej w trakcie postępowania podatkowego powinno być poparte wykazaniem możliwości przeprowadzenia takich czynności, których $\mathrm{np}$. nie można przeprowadzić $\mathrm{w}$ postępowaniu podatkowym, w przeciwnym razie nie znajduje to uzasadnienia. $Z$ tego punktu widzenia konieczne wydaje się ustalenie zakresu postępowania dowodowego prowadzonego $\mathrm{w}$ toku kontroli podatkowej oraz w trakcie postępowania podatkowego. Pomocny w tym zadaniu może okazać się poniższy schemat (zob. tab. 1).

Analizując przepisy zawarte w Dziale VI charakterystyczne w trakcie kontroli podatkowej są czynności, podejmowane w oparciu o element zaskoczenia (bez zawiadomienia art. 282c o.p., w tym na tzw.: legitymację - art. 284a o.p.). Ich głównym celem jest przede wszystkim zabezpieczenie materiału dowodowego czy przeciwdziałanie popełnieniu przestępstwa. Poza tym z przepisów działu nie wynika wprost, by sposób prowadzenia takich kontroli (poza aspektem zawiadomienia i wszczęcia na legitymację - art. 284a §1-1a) różnił się od sposobu prowadzenia kontroli wszczętej w sposób przewidziany w art. 284 o.p. i poprzedzonej zawiadomieniem o planowanym podjęciu kontroli. Biorąc jednak pod uwagę funkcję tego typu kontroli, zastosowanie tu znajdą w szczególności przepisy dotyczące m. in.: legitymowania osób, zabezpieczenia materiału dowodowego, oględzin, w tym oględzin z przeszukaniem. Kontrole podejmowane bez zawiadomienia $\mathrm{w}$ praktyce wiążą się jednak z koniecznością posiadania informacji lub wręcz dowodów, które uzasadniają ich podjęcie.

w relacji konkurencji w zakresie ustalenia stanu faktycznego sprawy. Wskazywał na to również Dzwonkowski i Zgierski [2006: 171].

${ }^{11}$ M. Rusinek [2002] zauważa, że ,,(..) nie wydaje się słusznym przyznawanie kompetencji do ponownego przeprowadzenia kontroli w każdej takiej sprawie. W następnym postępowaniu organ winien być związany ustaleniami dokonanej raz kontroli, chyba że sąd administracyjny wskazał na potrzebe usuniẹcia uchybień popełnionych w jej toku. I właśnie w ten sposób należy interpretować przesłankę niezbędności przeprowadzenia ponownej kontroli”. 
Tabela 1.

\begin{tabular}{|c|c|c|c|}
\hline \multicolumn{2}{|r|}{ Rodzaj dowodu } & Kontrola podatkowa & $\begin{array}{c}\text { Postępowanie } \\
\text { podatkowe }\end{array}$ \\
\hline \multicolumn{2}{|r|}{1} & 2 & 3 \\
\hline \multirow[t]{4}{*}{$\begin{array}{l}\text { Dowody } \\
\text { bezpośrednie }\end{array}$} & Oględziny: & $\begin{array}{l}\text { art. } 286 \S 1 \text { pkt } 3 \text {, art. } 198 \\
\text { w zw. z art. } 292 \text { o.p. i art. } 288 \\
\text { §1 i } 2 \text { o.p. }\end{array}$ & art. 190 i 198 o.p. \\
\hline & Przeszukanie: & $\begin{array}{l}\text { art. } 288 \S 1 \text { pkt } 2 \text { o.p. oraz } \\
\text { rozdział } 25 \text { k.p.k. w szcze- } \\
\text { gólności: art. } 217 \S 1-3, \\
\text { art. } 219-220 \S 1-3 \text {, art. } 222, \\
\text { art. } 224 \S 1-3 \text {, art. } 227, \\
\text { art. } 228 \S 1-3 \text { oraz art. } 148 \\
\text { k.p.k. }\end{array}$ & - \\
\hline & $\begin{array}{l}\text { Księgi podatkowe } \\
\text { Deklaracje podatkowe, }\end{array}$ & $\begin{array}{l}\text { art. 180, art. 181, art. } 193 \\
\text { w zw. z art. } 292 \text { o.p. }\end{array}$ & $\begin{array}{l}\text { art. } 180 \text {, art. } 181, \\
\text { art. } 193 \text { o.p. }\end{array}$ \\
\hline & Dokumenty urzędowe & $\begin{array}{l}\text { art. } 194 \text { o.p. w zw. z art. } 292 \\
\text { o.p. }\end{array}$ & art. 194 o.p. \\
\hline \multirow[t]{7}{*}{$\begin{array}{l}\text { Dowody } \\
\text { pośrednie }\end{array}$} & Powołanie biegłego & $\begin{array}{l}\text { art. } 286 \S 1 \text { pkt } 10 \text { o.p., } \\
\text { art. } 197 \S 1 \text {, art. } 180 \S 1 \text { i } 181 \\
\text { o.p. w zw. z art. } 292 \text { o.p. }\end{array}$ & $\begin{array}{l}\text { art. } 197 \text { §1 o.p., } \\
\text { art. } 180 \S 1 \text { i } 181 \text { o.p. }\end{array}$ \\
\hline & Przesłuchanie świadka & $\begin{array}{l}\text { art. } 286 \S 1 \text { pkt } 9 \text { o.p., art. } 195 \\
\text { i } 196 \text { o.p., art. } 180 \text { §1 i } 181 \\
\text { o.p. w zw. z art. } 292 \text { o.p. }\end{array}$ & $\begin{array}{l}\text { art. } 180 \text { \$1 i } 181 \text { o.p. } \\
\text { art. } 195 \text { i } 196 \text { o.p. }\end{array}$ \\
\hline & $\begin{array}{l}\text { Przesłuchanie kontrolowane- } \\
\text { go/strony }\end{array}$ & $\begin{array}{l}\text { art. } 286 \S 1 \text { pkt } 9 \text { o.p., } \\
\text { art. } 199 \text {, art. } 180 \S 1 \text { i } 181 \\
\text { o.p., w zw. z art. } 292 \text { o.p. }\end{array}$ & $\begin{array}{l}\text { art. } 199 \text { o.p., art. } 180 \\
\$ 1 \text { i } 181 \text { o.p. }\end{array}$ \\
\hline & $\begin{array}{l}\text { Przesłuchanie innych osób: } \\
\text { (pracownicy, upoważnieni } \\
\text { do reprezentowania w trakcie } \\
\text { kontroli, osoby współdziała- } \\
\text { jące) }\end{array}$ & art. $286 \S 1$ pkt 9 o.p. & $\begin{array}{l}\text { art. } 180 \S 1 \text { i } 181 \text { o.p. } \\
\text { oraz art. } 195 \text { i } 196 \\
\text { o.p. }\end{array}$ \\
\hline & $\begin{array}{l}\text { Oświadczenie o stanie ma- } \\
\text { jątkowym na konkretny } \\
\text { dzień }\end{array}$ & art. $285 \mathrm{a} \$ 3$ o.p. & - \\
\hline & \begin{tabular}{|l|} 
Informacje podatkowe, \\
dokumenty zgromadzone \\
w toku czynności sprawdza- \\
jących lub kontroli podatko- \\
wej (np.: prowadzonej przez \\
inny organ), z zastrzeżeniem \\
art. $284 \mathrm{a} \$ 3$, art. $284 \mathrm{~b} \S 3$ \\
i art. $288 \S 2$, oraz materiały \\
zgromadzone w toku postę- \\
powania karnego albo postę- \\
powania w sprawach \\
o przestępstwa skarbowe lub \\
wykroczenia skarbowe \\
\end{tabular} & $\begin{array}{l}\text { art. } 180, \text { art. } 181 \mathrm{w} \mathrm{zw} . \\
\mathrm{z} \text { art. } 292 \text { o.p. }\end{array}$ & art. 180, art. 181 o.p. \\
\hline & $\begin{array}{l}\text { Informacje dotyczące kontro- } \\
\text { lowanego pochodzące od } \\
\text { instytucji finansowych }\end{array}$ & $\begin{array}{l}\text { art. } 182-185 \text { o.p., art. } 180 \\
\S 1, w \text { zw. } z \text { art. } 292 \text { o.p. }\end{array}$ & $\begin{array}{l}\text { art. } 182-185 \text { o.p., } \\
\text { art. } 180 \S 1 \text { o.p. }\end{array}$ \\
\hline
\end{tabular}




\begin{tabular}{|c|c|c|c|}
\hline & 1 & 2 & 3 \\
\hline & $\begin{array}{l}\text { Czynności sprawdzające } \\
\text { wobec kontrahentów podatni- } \\
\text { ka wykonujących działalność } \\
\text { gospodarczą }\end{array}$ & art. 274 c o.p. ${ }^{(*)}$ & - \\
\hline & Wyjaśnienia & art. 287 §3-4 o.p. & $\begin{array}{l}\text { art. } 180 \text { i } 181 \text { o.p., } \\
\text { art. } 155 \S 1\end{array}$ \\
\hline $\begin{array}{l}\text { Dowody } \\
\text { nienazwane }\end{array}$ & $\begin{array}{l}\text { Inne niezbędne materiały } \\
\text { (dowody nienazwane) }\end{array}$ & $\begin{array}{l}\text { art. } 286 \S 1 \text { pkt } 5 \text { i } \S 2 \text { o.p., } \\
\text { art } 180 \S 1 \text { w zw. z art. } 292 \\
\text { o.p. }\end{array}$ & art. $180 \S 1$ o.p. \\
\hline $\begin{array}{l}\text { Zabezpiecze- } \\
\text { nie materiału } \\
\text { dowodowego }\end{array}$ & $\begin{array}{l}\text { Wydanie próbek, akt, ksiąg } \\
\text { i dokumentów, fotografowa- } \\
\text { nie, utrwalanie zapisu }\end{array}$ & $\begin{array}{l}\text { art. } 286 \S 1 \text { pkt 6, } \\
\text { art. } 286 \S 2 \text { pkt 1-2 o.p. }\end{array}$ & - \\
\hline & Spis z natury & art. $286 \S 1$ pkt 8 o.p. & - \\
\hline Zasady postęp & wania dowodowego & $\begin{array}{l}\text { art. } 122-123, \text { art. } 187, \text { art. } 190 \\
\S 2, \text { art. } 191-192 \text { w zw. } \\
\text { z art. } 292 \text { o.p. }\end{array}$ & $\begin{array}{l}\text { art. } 122-123, \\
\text { art. } 187, \text { art. } 190 \S 2, \\
\text { art. } 191-192 \text { o.p. }\end{array}$ \\
\hline
\end{tabular}

(*) Przepis art. 274c o.p. zastąpił dotychczasowy przepis art. 288a, który był zawarty w dziale VI odnoszący się do kontroli kontrahentów podatnika.

Art. 274c. §1. Organ podatkowy, w związku z prowadzonym postępowaniem podatkowym lub kontrolą podatkową, może zażądać od kontrahentów podatnika wykonujących działalność gospodarczą przedstawienia dokumentów, w zakresie objętym kontrolą u podatnika, w celu sprawdzenia ich prawidłowości i rzetelności. Z czynności tych sporządza się protokół.

§2. Jeżeli miejsce zamieszkania, siedziba lub miejsce wykonywania działalności kontrahenta kontrolowanego znajdują się poza obszarem działania organu przeprowadzającego kontrolę, czynności, o których mowa w §1, na zlecenie tego organu może także dokonać organ właściwy miejscowo.

\section{KONTROLA PODATKOWA A KONCEPCJA FUNKCJONALNA MODELU ORDYNACJI PODATKOWEJ ${ }^{12}$}

Zaprezentowana w Sejmie na początku 2013 r. koncepcja przebudowy Ordynacji podatkowej przewidywała takie ułożenie regulacji, aby poszczególne instytucje prawne znajdowały się w miejscach odpowiadających ich charakterowi prawnemu. Zgodnie z zaprezentowanymi założeniami przebudowa Ordynacji podatkowej powinna uwzględniać relacje między prawem materialnym i procedurą postępowania. Według koncepcji w systemie prawa podatkowego i w samej zresztą Ordynacji podatkowej poszczególne normy prawne można pogrupować według następujących funkcji: powstawania stosunku podatkowo-prawnego

${ }^{12}$ Koncepcja budowy ordynacji podatkowej w układzie funkcjonalnym - H. Dzwonkowski, zaprezentowana 8 stycznia 2013 r. w Sejmie podczas konferencji „Zmiany w ordynacji podatkowej. Poprawa jakości i uproszczenia”, zorganizowanej przez sejmową Komisję Finansów Publicznych oraz Biuro Analiz Sejmowych. Więcej na temat: http://www.poltax.pl/przebudowa_ordynacji_podatkowej/. 
obowiązku podatkowego, wymiaru zobowiązania i wykonywania zobowiązania. Poszczególne te funkcje odpowiadają zresztą etapom realizacji stosunku podatkowo-prawnego. Co za tym idzie, elementy układu Ordynacji podatkowej winny być wyznaczone właśnie przez porządek realizacji zobowiązania, przez który należy rozumieć jego powstawanie, wymiar, wykonywanie. Do takich też kategorii powinny zostać $\mathrm{w}$ możliwie największym stopniu przyporządkowane poszczególne przepisy Ordynacji.

W odniesieniu do zaprezentowanego układu, kontrola podatkowa może w mojej ocenie realizować się poprzez czynności, które ex post pozwalają na stwierdzenie prawidłowości realizacji stosunku podatkowo-prawnego przez podmioty prawa na poszczególnych jego etapach.

1. Czynności kontroli zgłaszania obowiązku podatkowego i rejestrowania zdarzeń związanych $\mathrm{z}$ obowiązkiem podatkowym:

- ustalenie czy dokonano ogólnego obowiązku rejestracyjnego (NIP) i obowiązków rejestracyjnych na potrzeby konkretnych podatków, zdarzeń podatkowych (np.: VAT UE, VAT-R etc.), ustalenie czy dochodzi do przejęcia praw i obowiązków podmiotów przekształconych (np. prawa do zaliczek uproszczonych, kontynuacji amortyzacji etc.),

- zebranie materiału dowodowego i jego zabezpieczenie.

\section{Czynności kontroli wymiaru zobowiązań:}

- ustalenie prawidłowości wykonania decyzji o charakterze wspomagającym wymiar - porozumienia w sprawie ustalania cen transakcyjnych,

- weryfikacja prawidłowości ustalenia wysokości zobowiązania podatkowego, wykonywania obowiązków o charakterze dokumentacyjno-ewidencyjnym, sprawozdawczo-informacyjnym (sprawdzenie wszystkich elementów wpływających na wysokość zobowiązania),

- zebranie materiału dowodowego oraz jego zabezpieczenie.

3. Czynności kontroli wykonywania zobowiązań mogą mieć na celu:

- zbadanie przyczyn niewykonania zobowiązania,

- zebranie materiału dowodowego na potrzebę zabezpieczenia wykonania zobowiązania podatkowego (art. 39 §1 - wezwanie kontrolowanego do złożenia oświadczenia o: nieruchomościach oraz prawach majątkowych, które mogą być przedmiotem hipoteki przymusowej; rzeczach ruchomych oraz zbywalnych prawach majątkowych, które mogą być przedmiotem zastawu skarbowego),

- weryfikacja korzystania $\mathrm{z}$ ulg, przyczyn powstania nadpłaty podatku, straty,

- zebranie materiału dowodowego oraz jego zabezpieczenie.

Wnioski płynące z powyższych rozważań, również wskazują na konieczność wyodrębnienia procedury kontroli podatkowej ze względu na jej szerokie zastosowanie. 


\section{POSTULATY}

Z uwagi na różnorodność rezultatów i przesłanek zastosowania procedury kontroli podatkowej, autonomiczny sposób jej regulacji znajduje swoje uzasadnienie. Nie oznacza to jednak, iż wszystkie rozwiązania przewidziane w dziale VI są bezdyskusyjne. Poddając analizie funkcjonalnej chociażby regulacje odnoszące się do czynności dowodowych można dojść do wniosku, że niektórym spośród nich powinno się nadać jednolity charakter. Nie znajduje bowiem uzasadnienia odmienne uregulowanie czynności polegającej na przeprowadzeniu oględzin (art. $286 \S 1$ pkt. 3, art. $288 \S 1$ pkt. 1) w trakcie kontroli podatkowej i ich ogólna podstawa zawarta $\mathrm{w}$ dziale IV o.p. Uprawnienia wiążące się z ewentualną możliwością naruszenia miru domowego (jak w przypadku art. 288 $\S 1$ pkt.1 o.p.) powinny być wyraźnie określone w ustawie - tymczasem nie ma takiej regulacji w dziale IV. Niektóre spośród dowodów przewidzianych w ramach kontroli podatkowej - nie znajdujących odzwierciedlenia explicite w ramach działu IV są możliwe do przeprowadzenia w ramach postępowania podatkowego, którego zakres jest z samego założenia najszerszy (np. wyjaśnienia). Doprecyzowaniu powinien ulec art. 274c o.p. którego §2 zaprzecza idei tej regulacji i może być dyskusyjny.

Ponadto, z uwagi na ścisłe relacje kontroli podatkowej i postępowania podatkowego, najważniejszym postulatem jest, by w ramach kontroli podatkowej zagwarantowana była realizacja wszystkich zasad postępowania, do czego odsyła art. 292 Ordynacji podatkowej. W związku z powyższym analizie powinny zostać poddane $\mathrm{m}$. in. następujące regulacje:

- art. 282c Ordynacji podatkowej jako realizacja zasady informowania w zakresie negatywnych przesłanek zawiadomienia o planowanym podjęciu kontroli,

- wyjątki od realizacji zasady trwałości decyzji ostatecznych w zakresie możliwości podejmowania ponownej kontroli $^{13} \mathrm{~W}$ związku $\mathrm{z}$ postępowaniem w sprawie stwierdzenia nieważności decyzji,

- realizacja zasady zaufania i szybkości postępowania w odniesieniu do braku precyzyjnego określenia czasu trwania kontroli,

- realizacja czynnego udziału strony/kontrolowanego w postępowaniu w odniesieniu do możliwości rezygnacji kontrolowanego z uczestnictwa w kontroli.

\footnotetext{
${ }^{13}$ Chodzi o tożsamość spraw co do przedmiotu, podmiotu, stanu faktycznego i prawnego.
} 


\section{TABELE PORÓWNAWCZE}

Tabela 2. Oględziny

\begin{tabular}{|c|c|c|c|c|}
\hline Procedura & $\begin{array}{c}\text { Czynności } \\
\text { sprawdzające }\end{array}$ & \multicolumn{2}{|c|}{ Kontrola podatkowa } & $\begin{array}{l}\text { Postępowanie } \\
\text { podatkowe }\end{array}$ \\
\hline $\begin{array}{l}\text { Podstawa } \\
\text { prawna }\end{array}$ & $\begin{array}{l}\text { Art. } 276 \S 1 \text { pkt. } 3 \\
\text { o.p. }\end{array}$ & $\begin{array}{l}\text { Art. } 286 \S 1 \\
\text { pkt. } 3\end{array}$ & Art. $288 \S 1$ o.p. & Art. $198 \S 1$ o.p. \\
\hline Przedmiot & $\begin{array}{l}\text { lokal mieszkalny } \\
\text { lub części tego } \\
\text { lokalu }\end{array}$ & $\begin{array}{l}\text { majątek podle- } \\
\text { gający kontroli }\end{array}$ & $\begin{array}{l}\text { teren, budynek, lokal } \\
\text { mieszkalny }\end{array}$ & $\begin{array}{l}\text { szeroki zakres: } \\
\text { osoba, dokumen- } \\
\text { ty, nierucho- } \\
\text { mość, miejsce, } \\
\text { rzecz ruchoma; } \\
\text { granice wyzna- } \\
\text { czone przez } \\
\text { zasadę prawdy } \\
\text { materialnej(*) }\end{array}$ \\
\hline Przesłanki & $\begin{array}{l}\text { zweryfikowanie } \\
\text { zgodności stanu } \\
\text { faktycznego } \\
\text { z danymi wynika- } \\
\text { jącymi z deklaracji } \\
\text { oraz z innych } \\
\text { dokumentów } \\
\text { potwierdzających } \\
\text { poniesienie wy- } \\
\text { datków na cele } \\
\text { mieszkaniowe }\end{array}$ & $\begin{array}{l}\text { pomoc } \\
\text { w ustaleniu } \\
\text { stanu faktycz- } \\
\text { nego - w za- } \\
\text { kresie kontroli } \\
\text { określonym na } \\
\text { upoważnieniu }\end{array}$ & $\begin{array}{l}\text { samoistnie (pkt. 1): } \\
\text { jeżeli ww. nieruchomości } \\
\text { zostały wskazane } \\
\text { - jako miejsce wykony- } \\
\text { wania działalności go- } \\
\text { spodarczej lub } \\
\text { - jako siedziba kontrolo- } \\
\text { wanego, } \\
\text { - jeśli jest to niezbędne } \\
\text { dla ustalenia lub określe- } \\
\text { nia wysokości zobowią- } \\
\text { zania podatkowego } \\
\text { z przeszukaniem (pkt. 2): } \\
\text { - jeśli powzięto informa- } \\
\text { cję o prowadzeniu nie- } \\
\text { zgłoszonej do opodatko- } \\
\text { wania działalności go- } \\
\text { spodarczej albo } \\
\text { - gdy są tam przecho- } \\
\text { wywane przedmioty, } \\
\text { księgi podatkowe, akta } \\
\text { lub inne dokumenty } \\
\text { mogące mieć wpływ na } \\
\text { ustalenie istnienia obo- } \\
\text { wiązku podatkowego lub } \\
\text { określenie wysokości } \\
\text { zobowiązania podatko- } \\
\text { wego }\end{array}$ & $\begin{array}{l}\text { pomoc w ustale- } \\
\text { niu stanu fak- } \\
\text { tycznego - jeśli } \\
\text { ma to istotne } \\
\text { znaczenie dla } \\
\text { sprawy }\end{array}$ \\
\hline $\begin{array}{l}\text { Charakter } \\
\text { posiłkowy }\end{array}$ & Zgoda podatnika & - & $\begin{array}{l}\text { Zgoda kontrolowane- } \\
\text { go/prokuratora }\end{array}$ & - \\
\hline
\end{tabular}

(*) Wyrok NSA z 14 października 2011 r., III FSK 1526/10. 
Tabela 3. Kryteria kontroli - klasyfikacja

\begin{tabular}{|c|c|c|}
\hline \multicolumn{2}{|c|}{ Kryterium } & Typy kontroli (przykłady) \\
\hline \multirow[t]{3}{*}{ Przedmiotowe } & Rodzaj podatku & $\begin{array}{l}\text { W zakresie podatków dochodowych, podatku od towa- } \\
\text { rów i usług, od spadków i darowizn, podatku tonażowe- } \\
\text { go, od czynności cywilnoprawnych, podatków i opłat } \\
\text { lokalnych }\end{array}$ \\
\hline & Czynnik czasu & 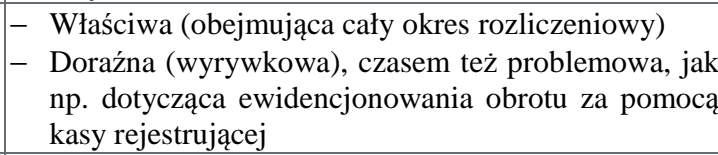 \\
\hline & Obszar ryzyka & $\begin{array}{l}\text { Wynikające z planów kontroli dotyczącej np. transakcji } \\
\text { wewnątrzwspólnotowych, podmiotów świadczących } \\
\text { usługi budowlane, dokonujących obrotu paliwami, } \\
\text { dokonujących transakcji gospodarczych za pomocą } \\
\text { internetu }^{(*)}\end{array}$ \\
\hline \multirow[t]{2}{*}{ Podmiotowe } & Podmiot bierny & $\begin{array}{l}\text { Kontrole wobec: podatnika, płatnika, inkasenta lub } \\
\text { następcy prawnego oraz wobec przedsiębiorcy niezależ- } \\
\text { nie od tego czy jest jednym z wyżej wymienionych } \\
\text { podmiotów. }\end{array}$ \\
\hline & Podmiot czynny & $\begin{array}{l}\text { Kontrole prowadzone przez: organy podatkowe I instan- } \\
\text { cji (art. } 281 \S 1 \mathrm{i} \S 3 \text { ) oraz inne np. organy kontroli skar- } \\
\text { bowej czy potencjalnie tzw. „spec organy”(**) }\end{array}$ \\
\hline \multirow[t]{2}{*}{ Procedury } & Gwarancji & $\begin{array}{l}\text { - Z zawiadomieniem o planowanym podjęciu kontroli } \\
\text { - } \\
\text { Bez zawiadomienia o planowanym podjęciu kontroli } \\
\text { - w tym kontrola na legitymację (ad hoc) }\end{array}$ \\
\hline & \begin{tabular}{|l|} 
Sposób \\
prowadzenia \\
(relacji względem \\
innych procedur)
\end{tabular} & $\begin{array}{ll}- & \text { Samoistna } \\
- & \text { Na potrzeby postępowania podatkowego (w trakcie } \\
& \text { postępowania podatkowego) }\end{array}$ \\
\hline Wyniku & \multicolumn{2}{|c|}{$\begin{array}{l}\text { - Pozytywna - stwierdzająca nieprawidłowości, w tym też nie wpływające } \\
\text { na wysokość zobowiązania podatkowego } \\
\text { - Negatywna - nie stwierdzająca nieprawidłowości }\end{array}$} \\
\hline Funkcjonalne* & \multicolumn{2}{|c|}{$\begin{array}{l}\text { - Kontrola zgłaszania obowiązku podatkowego i rejestrowania zdarzeń } \\
\text { związanych z obowiązkiem podatkowym } \\
\text { - Kontrola wymiaru zobowiązań } \\
\text { - Kontrola wykonywania zobowiązań }\end{array}$} \\
\hline
\end{tabular}

(*) Przykładowe tematy kontroli zawarte w Krajowym Planie Dyscypliny Podatkowej na 2009 rok. Ministerstwo Finansów realizując założenia Strategii Zarządzania Ryzykiem Zewnętrznym, którego celem jest osiągnięcie wysokiego poziomu i jakości wypełniania obowiązków podatkowych przekazuje co roku organom skarbowym takie plany do realizacji. Tematy jednak ulegają modyfikacji.

${ }^{(* *)}$ Zgodnie z art. 13a o.p. Rada Ministrów może, w drodze rozporządzenia, nadać uprawnienia organów podatkowych: Szefowi Agencji Wywiadu, Szefowi Agencji Bezpieczeństwa Wewnętrznego, Szefowi Centralnego Biura Antykorupcyjnego, Szefowi Służby Wywiadu Wojskowego, Szefowi Służby Kontrwywiadu Wojskowego, gdy jest to uzasadnione ochroną tajemnicy państwowej i wymogami bezpieczeństwa państwa. 


\section{BIBLIOGRAFIA}

B og u c k a I., 2000, Funkcje prawa. Analiza pojęcia, Wolters Kluwer Polska, Kraków.

Dębowska-Romanowska T., 1998, Obliczenie podatku a gwarancje praw obywatelskich, „Państwo i Prawo”, nr 7.

D z w on kow ski H., Zg i er s ki Z., 2006, Procedury podatkowe, Difin, Warszawa.

D z w o n kow s ki H., 2003, Powstawanie i wymiar zobowiazań podatkowych, Dom Wydawniczy $\mathrm{ABC}$, Warszawa.

D z w o n k o w s ki H., 2004, Samowymiar zobowiazań podatkowych, „Państwo i Prawo”, nr 12.

Glosa do wyroku WSA w Krakowie z 9.2.2007 r., I SA/Kr 923/05, „Monitor Podatkowy” 2007, nr 10.

Kaczyński T., Charkiewicz M., 2012, Skutki ograniczenia czasu trwania kontroli podatkowej, (w:) R. Dow g i e r (red.), Ordynacja podatkowa. Kontrola realizacji zobowiąań podatkowych, Temida 2, Białystok.

Kosińska R, Wolatnows ki P., 2007, Prawo do korekty deklaracji po zakończeniu postepowania kontrolnego, (w:) Ordynacja podatkowa w praktyce: materiaty konferencyjne, Temida 2 , Białystok.

K u b a cki R., B a r to si e wi c z A., 2007, Charakter terminu do ztożenia zastrzeżeń do protokołu kontroli podatkowej (skarbowej) Glosa do wyroku WSA w Krakowie z 9.2.2007 r., I SA/Kr 923/05, „Monitor Podatkowy” 2007, nr 10.

Kurowski L., S ochacka-Krysiak H., 1990, Kontrola finansowa - organizacja i funkcjonowanie, PWE, Warszawa.

Malezini A., Zalew ski D., 2010, Zakończenie kontroli podatkowej przedsiębiorcy w orzecznictwie sąów administracyjnych, „Przegląd Podatkowy”, nr 11.

Malezini A., 2007, Uwagi do referatu „Procedury kontrolne-problemy praktyczne”, (w:) Ordynacja podatkowa w praktyce: materiaty konferencyjne, Temida 2, Białystok.

Mastalski R., Zubrzycki J., 2000, Ordynacja podatkowa. Komentarz, OW Unimex, Wrocław.

M a stern a k M., 1998, Rodzaje postępowań w sprawach podatkowych, (w:) Księga pamiatkowa ku czci docenta Eligiusza Drgasa. Studia z zakresu Ordynacji podatkowej, „Dom Organizatora" TNOiK, Toruń.

Niezgódka-Medek M., 2007, (w:) S. Babiarz, B. Dauter, B. Gruszczyński, R. Hauser, A. Kabat, M. Niezgódka-Medek, Ordynacja podatkowa. Komentarz, wydanie VII, Lexis Nexis, Warszawa, art. 281.

Pietrasz P., 2007, Procedury kontrolne - problemy praktyczne, (w:) Ordynacja podatkowa w praktyce: materiaty konferencyjne, Temida 2 , Białystok.

Popławki M., 2009, Kontrola podatkowa, (w:) J. B rolik, R. Dowgi er, L. Etel, C. Kosikowski, P. Pietrasz, S. Presnarowicz, W. Stachurski, Ordynacja podatkowa. Komentarz, Wolters Kluwer Polska, Warszawa.

R u s in e k M., 2002, Komentarz do ustawy z dnia 12 września 2002 r. o zmianie ustawy Ordynacja podatkowa oraz o zmianie niektórych innych ustaw (LEX/el., 2002).

Ustawa z dnia 29 sierpnia 1997 r. Ordynacja podatkowa, DzU 2005, nr 8, poz. 60.

Ustawa z dnia 7 listopada 2008 r. o zmianie ustawy - Ordynacja podatkowa oraz niektórych innych ustaw, DzU 2008, nr 209, poz. 1318.

Wyrok NSA z 14 października 2011 r., III FSK 1526/10.

Wyrok NSA z 15 lipca 2011 r., I FSK 849/11.

Z d a no wi c z J., 1998, Kontrola podatkowa w świetle ordynacji podatkowej, „Monitor Podatkowy", nr 10. 


\section{THE LEGAL CHARACTER OF A TAX AUDIT IN FUNCTIONAL ASPECT}

Article discuss the legal nature of a tax audit procedure with regard to the concept of the function of the law. The text analyzes the position of tax audit procedure in the context of other tax procedures provided for in the Tax Code. Article also refers to the functional concept of the construction of the Tax Code considering the location of a tax audit in the proposed system. The author justifies the need to extract a tax audit as a stand-alone procedure and proposes some directions of change within the institution.

Key words: tax audit, functions, result of tax audit, the purpose of tax audit. 